\title{
Communication
}

[Comunicação]

\section{Atrial septal defect in an elderly dog}

[Defeito de septo atrial em cão idoso]

\author{
G.A.O. Cavalcanti ${ }^{1}$, L.S. Tatibana ${ }^{1}$, M.S. Varaschin $^{2}$, R.B. Araújo ${ }^{1}$, A.P. Costa Val ${ }^{1}$ \\ ${ }^{1}$ Escola de Veterinária - UFMG \\ Av. Antônio Carlos, 6627 \\ 30270-901 - Belo Horizonte, MG. \\ ${ }^{2}$ Departamento de Medicina Veterinária - UFLA - Lavras, MG.
}

Atrial septal defect (ASD) is an uncommon cardiac malformation in dogs. ASD is characterized by communication between the two atria due to a defect in the interatrial septum (Kittleson and Kienle, 1998; Guglielmini et al., 2002; Chetboul et al., 2006). Ostium secundum ASDs are most commonly seen in dogs (Guglielmini et al., 2002; Sanders et al., 2005, MacDonald, 2006). Regardless of type, isolated ASD usually result in a left-to-right shunting across the defect (Guglielmini et al., 2002). The clinical sings of congenital heart disease occur in animals younger than three-year-old and they are rarely seen in aged dogs (Kittleson and Kienle, 1998; Guglielmini et al., 2002; Chetboul et al., 2006). Echocardiography is necessary to determine the diagnosis and severity of the shunt (Kittleson and Kienle, 1998). Treatment of small septal defects is not necessary. Medical treatment consists of systemic arterial vasodilation to reduce the severity of the shunt. Paliative medical therapy with diuretics and angiotensin converting enzyme inhibitors is used for treatment of congestive heart failure. Positive inotropic drugs may be needed if there is myocardial failure, often as a result of severe aortic insufficiency (Kittleson and Kienle, 1998).

The present report describes the clinical, electrocardiographic, radiographic, echocardiographic, and necropsy findings in the first case report of an elderly dog with ASD in Latin America.

An 11-year-old female Pinscher, weighting $5.4 \mathrm{~kg}$ was attended at a teaching Veterinary Hospital with a history of anorexia and depression. At physical examination, reduction of heart sounds, jugular pulse, tachypnea, and peritoneal fluid were evidenced. Pleural effusion was evident on both ventrodorsal and lateral views, whereas an increase in the right atrial size and pulmonary overcirculation were visualized on the ventrodorsal radiograph (Figure 1).

Transthoracic echocardiography was performed which revealed a severe dilated right side of the heart (M-mode right ventricular diastolic diameter $=9.4 \mathrm{~mm}$; reference value $=0.3 \mathrm{~mm}$ ) (Kittleson and Kienle, 1998), enlargement of the main pulmonary artery, and thickened atrioventricular valve leaflets. A normal left side of the heart was characterized by left atrium:root aortic ratio in two-dimensional=1:4 (reference range less than 1:6) (Rishniw and Erb, 2000) and M-mode left ventricular diastolic diameter = $18 \mathrm{~mm}$ (reference value $<24 \mathrm{~mm}$ ) (Kittleson and Kienle, 1998). The fractional shortening (FS) was high (58\%; reference value, 32-45\%) (Kittleson and Kienle, 1998) and showed an increase in systolic function, and there was paradoxal septal motion. Moreover, both colorflow and spectral Doppler images performed during the transthoracic echocardiography of the left apical four-chamber view demonstrated severe tricuspid insufficiency and mild to moderate mitral regurgitation.

Besides that, the echocardiography demonstrated a large interatrial communication, $0.7 \mathrm{~cm}$ in length, at the right parasternal long axis view and color Doppler allowed the confirmation of a left-

Recebido em 16 de março de 2010

Aceito em 8 de fevereiro de 2011

E-mail: guialbuquerque@yahoo.com. 
to-right shunt (Figure 2A). In addition, a continuous flow was observed by spectral Doppler echocardiography at the defect region (peak velocity, 2.53m/s; estimated pressure gradient from modified Bernoulli equation, 25.60mmHg).

Routine haematological and biochemical (aspartate aminotransferase, triglycerides, total bilirubin, direct bilirubin, indirect bilirubin, gama glutamyl transferase, calcium, potassium, glucose, urea nitrogen, creatinine, total plasma protein, albumin, globulin, and creatine kinase) analyses were normal. However, the alkaline phosphatase (AP), alanine aminotransferase (ALT), bilirubin (BIL), phosphorus (P), and magnesium (Mg) values were elevated (AP 337U/L, reference value 20-156U/L; ALT $117 \mathrm{U} / \mathrm{L}$, reference value $10-109 \mathrm{U} / \mathrm{L} ; \mathrm{BIL}$ $0.95 \mathrm{mg} / \mathrm{dL}$, reference value $0.1-0.5 \mathrm{mg} / \mathrm{dL} ; \mathrm{Mg}$ $3.8 \mu \mathrm{g} / \mathrm{dL}$, reference value $1.6-2.4 \mu \mathrm{g} / \mathrm{dL}$; and $\mathrm{P}$ $6.1 \mu \mathrm{g} / \mathrm{dL}$, reference value 2.9-5.3 $\mu \mathrm{g} / \mathrm{dL}$ ) (GarciaNavarro and Pachaly, 1994).

The abdominal ultrasound revealed ascites and congestive hepatomegaly. Laboratory analyses of peritoneal fluid revealed simple transudate. The treatment in the hospital consisted of oxigenoterapy, drainage of peritoneal fluid, intravenous (IV) administration of furosemide $2 \mathrm{mg} / \mathrm{kg}$ three times a day (TID), and oral (PO) hydrochlorothiazide $1 \mathrm{mg} / \mathrm{kg}$ twice a day (BID). It was prescribed as home treatment furosemide $4 \mathrm{mg} / \mathrm{kg}$ TID, PO and hydrochlorthiazide $2 \mathrm{mg} / \mathrm{kg}$ BID, PO. However, no clinical improvement was observed in ten days and euthanasia was performed. Necropsy demonstrated a secondary type of interatrial communication, $0.8 \mathrm{~cm}$ in length, thickening of the atrioventricular valves, pleural effusion, hepatic congestion, and peritoneal fluid (Fig. 2B).

Three types of ASD have been defined, according to the location of the defect within the interatrial septum: primum ASD is located in the most apical portion of the atrial septum; secundum ASD involves the region of the fossa ovalis, and the sinus venosus ASD is located in the upper portion of the septum (Chetboul et al., 2006). Ostium secundum ASD is most commonly seen in dogs (Kittleson and Kienle, 1998; Guglielmini et al., 2002; Chetboul et al.,
2006; MacDonald, 2006) and this defect was observed in this present report. Regardless of type, isolated ASD usually result in a left-to-right shunting across the defect because the left side of the heart has a higher pressure than the chambers of the right side of the heart. This extra blood from the left atrium may cause a volume overload in both right atrium and right ventricle, which if left untreated, can result in enlargement of the right side of the heart (Chetboul et al., 2006). The right volume overload may causes ascite, pleural effusion, pulmonary overcirculation, paradoxal septal motion, and enlargement of the main pulmonary artery (Kittleson and Kienle, 1998), seen in this present case.

As in humans and in small animals, ostium secundum ASD was found to be the most common form of the disease. In an animal retrospective study, with 156 cases of ASD (Chetboul et al., 2006), the right-to-left shunting was detected in under $10 \%$ of cases, and in only one case was considered the result of a large ASD. In other cases, it was secondary to a concomitant heart disease causing increased right-side cardiac pressure.

In humans, ASD constitute $30 \%$ to $40 \%$ of congenital heart disease and is twice more prevalent in females than males (Kittleson and Kienle, 1998). In dogs, the Boxer breed is more likely to present ASD than any other canine breeds and the gender prevalence is controvertial (Tidholm, 1997; Kittleson and Kienle, 1998; Guglielmini et al., 2002; Chetboul et al., 2006)

ASD is considered relatively rare in veterinary medicine. Its prevalence has been reported to vary from 0.7 to $3.7 \%$ of all canine congenital cardiovascular anomalies (Tidholm, 1997; Kittleson and Kienle, 1998; Guglielmini et al., 2002). However, modern echocardiographic and Doppler techniques offer a good view of the morphology of the interatrial septum; thus, facilitating earlier detection of ASD in awaken animals (Chetboul et al., 2006). The echocardiography combined with color-flow Doppler mode was the method that is chosen to confirm ASD and to determine the severity of the shunt (Kittleson and Kienle, 1998; Sanders et al., 2005). 

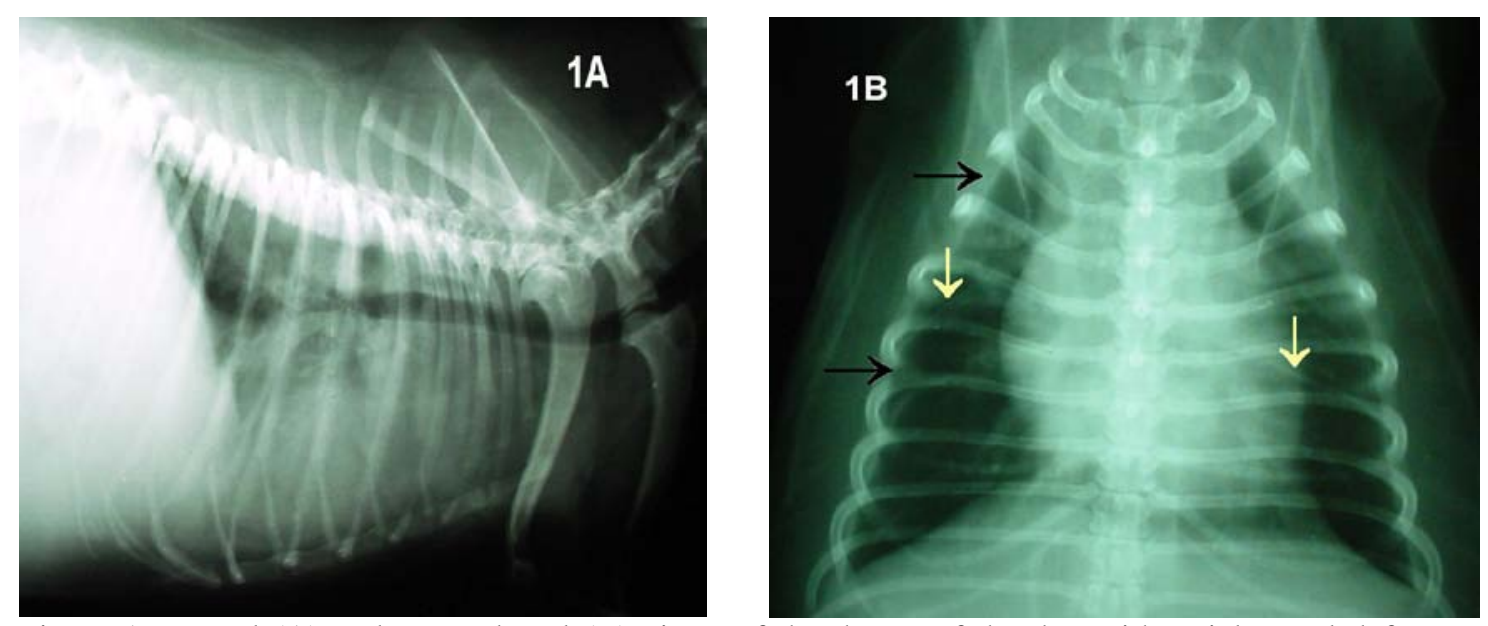

Figure 1. Lateral (A) and ventrodorsal (B) views of the thorax of the dog with atrial septal defect and pleural effusion. In the lateral view (A) there is opacification of the cranial aspect of the thorax. The heart was obscured and the lungs are displaced from the thoracic wall by the fluid. In the ventrodorsal view (B), there were visible interlobar fissures (yellow arrows), soft tissue opacity separating lung from thoracic wall (black arrows), and cardiomegaly with marked enlargement of right atrium.
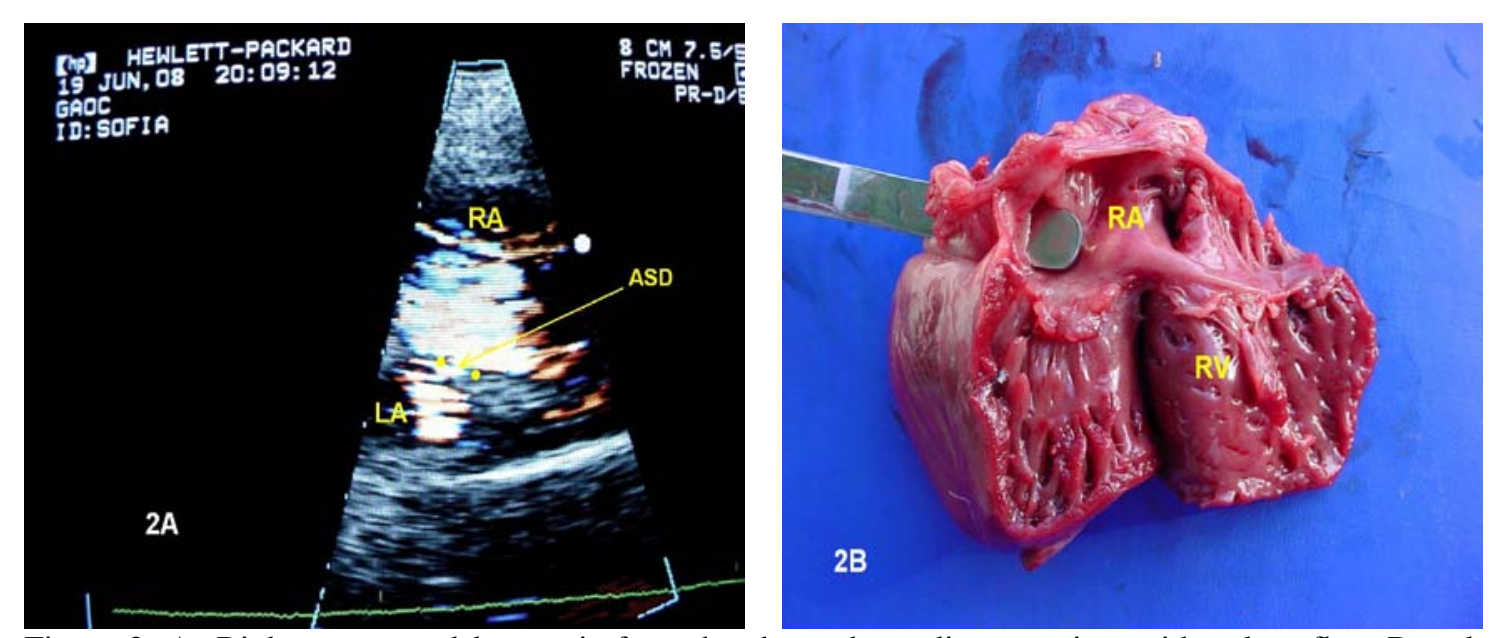

Figure 2. A- Right parasternal long-axis four chamber echocardiogram view with colour-flow Doppler echocardiogram, demonstrating a left-to-right flow across the atrial septal defect (ASD). B- Right heart at necropsy exhibiting right atrium (RA) and right ventricle (RV) enlargement, thickening tricuspid valve leaflets, and ASD (forceps handle). LA- left atrium; RA- right atrium; RV-right ventricle; ASD- atrial septal defect.

ASD is usually a well-compensated disease and clinical signs are related to a concurrent heart disease. Moreover, in an animal study with 156 cases of ASD (Chetboul et al., 2006), 90\% of affected animals belonged to the New York Heart Association (NYHA) class 1 and only one to the NYHA class 4 . In the present case, it is believed that the onset of clinical signs in the elderly dog was due to increase erratic ASD flow, and it was secondary to the increase of mitral degeneration, and to the best of the knowledge of the authors, any similar case reported of ASD has been previously described in dog. Only one case related a dog with ASD and clinical heart sign in aged dog was found, but this animal presented ostium secundum type ASD, dilated cardiomyopathy, and an echogenic rounded mass in the right atrium, which was interpreted as a cardiac thrombus in echocardiography, and a post-mortem examination was not carried out (Guglielmini et al., 2002). 
In the present case, there are transaminasis (AST and ALT) and cholestatic (AP and BIL) abnormalities and its possible to take place in heart failure especially in cardiac right failure (Lau et al., 2002). The tricuspid regurgitation was severe and indicated pulmonary hypertension because the gradient pressure in the right atrium was $51.84 \mathrm{mmHg}$ (modified Bernoulli equation) (Kittleson and Kienle, 1998), and it may be contributed to high levels of all hepatic function tests. However, no paper about liver function tests and cardiac failure on dogs was found.

In this report, there was increase in $\mathrm{P}$ and $\mathrm{Mg}$ at biochemical analyses. When cardiac output decreases, renal blood flow decreases. This decrease is probably disproportionately high compared with other organs because of afferent renal arteriolar constriction, with occurs secondary to sympathetic stimulation. In humans, renal blood flow is normally $20 \%$ of the cardiac output, whereas in heart it can fall to $10 \%$. The net effect of the decrease in renal blood flow is a decrease in glomerular filtration rate which possibly increases serum levels of urea nitrogen (BUN), creatinine, $\mathrm{Mg}$, and $\mathrm{P}$ (Kittleson and Kienle, 1998). However, in the present case, there was an increase only in these two electrolytes, and the causes of the BUN and the creatinine have not increased were not clear.

The treatment of small septal defects is not necessary. Definitive treatment of large left-to- right shunting defects is a patch closure under cardiopulmonary bypass or by transcatheter closure techniques (Sanders et al., 2005). An alternative is pulmonary artery banding, which is used to increase the pulmonary artery resistance (MacDonald, 2006). Medical treatment consists of systemic arterial vasodilation to reduce the severity of the shunt. Paliative medical therapy with diuretics and angiotensin converting enzyme inhibitors is used for treatment of congestive heart failure. Positive inotropic drugs may be needed if there is myocardial failure, often as a result of severe aortic insufficiency (MacDonald, 2006).

In human beings, the advent of echocardiography led to the recognition of a high incidence of apparent mitral valve prolapse, and an association between secundum defects and floppy mitral valves has been observed (Nagata et al., 1983). In this present case, the atrioventricular valves were thickened, there was not mitral prolapsed, and histological examination showed myxomatous changes in collagen; thus, this case is not similar to those seen in the humans. Therefore, adult and elderly dogs may develop cardiac insufficiency due to increase in ASD flow, secondary to mitral myxomatous valvular degeneration.

Keywords: dog, interatrial communication, myxomatous valvular

\section{RESUMO}

Atendeu-se uma cadela de 11 anos de idade, em hospital veterinário escola, apresentando anorexia, pulso jugular, taquipnéia e ascite. As radiografias torácicas mostraram efusão pleural. O exame ecocardiográfico identificou comunicação interatrial (CIA) grande, espessamento e insuficiência das valvas atrioventriculares. O tratamento foi realizado sem que houvesse melhora clínica significativa. O exame necroscópico confirmou a comunicação interatrial do tipo ostium secundum. Acredita-se que a apresentação dos sinais clínicos em cão idoso foi devido ao aumento do fluxo errático pelo defeito, secundário à degeneração da valva mitral. Concluise que a CIA pode causar sinais clínicos em animais adultos.

Palavras-chave: cadela, comunicação interatrial, ecocardiografia, degeneração mixomatosa crônica

\section{REFERENCES}

CHETBOUL, V.; CHARLES, V.; NICOLLE, A. et al. Retrospective study of 156 atrial septal defects in dogs and cats (2001-2005). J. Vet. Med. A, v.53, p.179-184, 2006.
GARCIA-NAVARRO, C.E.K.; PACHALY, J.R. (Ed). Manual de hematologia veterinária. São Paulo: Varela, 1994. 169p.

GUGlielMiNI, C.; DIANA, A.; PIETRA, M. et al. Atrial septal defect in five dogs. J. Small Anim. Pract., v.43, p.317-322, 2002. 
KITTLESON M.D.; KIENLE R.D. (Ed). Small animal cardiovascular medicine. St Louis: Mosby, 1998. 603p.

LAU, G.T.; TAN, H.C.; KRITHARIDES, L. Type of liver dysfunction in heart failure and its relation to the severity of tricuspid regurgitation. Am. J. Cardiol., v.90, p.1405-1409, 2002.

MACDONALD, K.A. Congenital heart diseases of puppies and kittens. Vet. Clin. N. Am.: Small Anim. Pract., v.36, p.503-531, 2006.

NAGATA, S.; NIMURA, Y.; SAKAKIBARA, $H$. et al. Mitral valve lesion associated with secundum atrial septal defect: Analysis by real time two dimensional echocardiography. $\mathrm{Br}$. Heart J., v.49, p.51-58, 1983.
RISHNIW, M.; ERB, H.N. Evaluation of four 2dimensional echocardiographic methods of assessing left atrial size in dogs. J. Vet. Intern. Med., v.14, p.429-435, 2000.

SANDERS, R.A.; HOGAN, D.F.; GREEN, H.W. et al. Transcatheter closure of an atrial septal defect in a dog. J. Am. Vet. Med. Assoc., v.227, p.430-434, 2005.

TIDHOLM, A. Retrospective study of congenital heart defects in 151 dogs. J. Small Anim. Pract., v.38, p.94-98, 1997. 